\title{
The integration of environmental objectives in the common agricultural policy_partisan politics in the European Parliament
}

\author{
Colette S. Vogeler $(\mathbb{D}$
}

Received: 11 January 2021 / Revised: 1 September 2021 / Accepted: 6 November 2021 / Published online: 10 December 2021

(C) The Author(s) 2021

\begin{abstract}
This study examines the policy preferences of political groups in the 8th European Parliament regarding the design of agricultural policy and the integration of environmental goals therein. Due to the high degree of Europeanization of the Common Agricultural Policy, the analysis of party positions at the EU level is particularly interesting. To what extent are the positions of political groups changing against the background of the increasing public awareness for environmental and animal welfare issues in agricultural policy? By means of a discourse network analysis of the plenary debates on selected policy proposals during the 8th term of the European Parliament, the positions of the political groups in agricultural policymaking are explored. The comparative analysis clearly reveals differences in problem perceptions and preferred policy solutions between the different political groups. Substantive differences are apparent between the EPP on the one side and the Greens/EFA and the GUE/NGL on the other side. EPP members still mostly represent traditional agricultural goals such as food security and income support for farmers, whereas the Greens/EFA and the GUE/NGL deputies promote a change towards a more environmentally and animal welfare friendly agricultural policy. At the same time, the analysis reveals a broad consensus across political groups regarding the general need to increasingly integrate sustainability concerns in the design of the future Common Agricultural Policy.
\end{abstract}

Keywords Agricultural policy · Discourse network analysis · Environmental policy $\cdot$ European parliament $\cdot$ Partisan politics

Colette S. Vogeler $(\bowtie)$

Institute of Comparative Politics and Public Policy, TU Braunschweig, Bienroder

Weg 97, 38106 Braunschweig, Germany

E-Mail: colette.vogeler@tu-braunschweig.de

Chair of Comparative Public Administration and Policy Analysis, German University of

Administrative Sciences Speyer, Speyer, Germany 


\section{Die Integration umweltpolitischer Ziele in der Gemeinsamen Agrarpolitik - Parteiendifferenzen im Europäischen Parlament}

Zusammenfassung Diese Studie analysiert die Policy Präferenzen der Fraktionen im 8. Europäischen Parlament hinsichtlich der Gestaltung der Agrarpolitik und der Integration von Umweltzielen in diese. Aufgrund des hohen Europäisierungsgrades der Gemeinsamen Agrarpolitik ist die Analyse der Parteipositionen auf EU-Ebene von besonderem Interesse. Inwieweit verändern sich die Positionen der Fraktionen vor dem Hintergrund des zunehmenden öffentlichen Bewusstseins für Umwelt- und Tierschutzbelange in der Agrarpolitik? Mittels einer Diskursnetzwerkanalyse der Plenardebatten zu ausgewählten Policy Proposals während der 8. Legislaturperiode des Europäischen Parlaments werden die Positionen der unterschiedlichen Fraktionen in der Agrarpolitik untersucht. Die vergleichende Analyse offenbart deutliche Unterschiede in der Problemwahrnehmung und den präferierten Policy Lösungen zwischen den Fraktionen. Substanzielle Unterschiede zeigen sich zwischen der EVP auf der einen Seite und den Grünen/EFA sowie der GUE/NGL auf der anderen Seite. Die EVP-Mitglieder vertreten nach wie vor überwiegend traditionelle agrarpolitische Ziele wie Ernährungssicherheit und Einkommensunterstützung für Landwirte, während die Abgeordneten der Grünen/EFA und der GUE/NGL für einen Policy Wandel hin zu einer umwelt- und tierschutzfreundlicheren Agrarpolitik eintreten. Gleichzeitig zeigt die Analyse einen breiten Konsens zwischen den Fraktionen hinsichtlich der generellen Notwendigkeit, Nachhaltigkeitsaspekte bei der Gestaltung der zukünftigen Gemeinsamen Agrarpolitik verstärkt zu berücksichtigen.

Schlüsselwörter Agrarpolitik · Diskursnetzwerkanalyse · Umweltpolitik · Europäisches Parlament · Parteiendifferenzen

\section{Introduction}

Agricultural activities and in particular the resource-intensive livestock farming contribute significantly to the overexploitation and to the pollution of natural resources (Möck et al. 2019). A sustainable transformation of the agricultural and the food system is therefore one of the greatest challenges at the intersection of agricultural and environmental policymaking. In addressing these challenges the European Union has a particularly important role, given that agricultural policy is one of the most Europeanized policy areas (Töller 2010). Historically, European agricultural policy has been oriented towards the goals of food security and the securing of farmers' income (Coleman et al. 1996; Skogstad 1998). The European Union's Common Agricultural Policy (CAP) was historically based on these premises and created incentives to increase production, which contributed to a strong intensification and regional concentration of agricultural activities and partly even to overproduction (Daugbjerg and Swinbank 2016; Skogstad 1998). The political focus on economic productivity and producer's interests has for long prevented the holistic consideration of environmental objectives in the EU's agricultural policy (Alons 2017). Beginning in the 1990s agri-environmental schemes were incorporated in the CAP. Since then, 
environmental as well as animal welfare policy objectives have gained importance (Daugbjerg and Swinbank 2016; Roederer-Rynning 2003; Vogeler 2019). In the past decade, policy changes were passed that aimed at integrating changing socio-economic demands in agricultural policy, e.g. the financial compensation of farmers for the provision of public goods such as ecosystem services (Henke et al. 2018). Despite these advancements in terms of sustainability, the so-called greening policies still remain highly contested and are often sacrificed for the benefit of competitiveness and productivity (Greer 2017; Grant 2017).

At the national level the traditional interests of the farming community were often pooled in conservative political parties, such as in Germany among Christian Democrats or in the UK within the Party of Wales or the Scottish National Party (Tosun 2017). The literature assumes that the compartmentalization of agricultural policy made it difficult for other than farming interests to get involved in agricultural policymaking (Daugbjerg and Feindt 2017). Compartmentalization refers to the relative closeness of the policy subsystem and the comparatively high homogeneity of actors and interests surrounding traditional agricultural goals such as food security or income support. Especially with the rise of environmental interests and ideas in combination with changing consumer demands, the protected agricultural subsystem came under pressure. These developments go along with an increasing realignment of agricultural policy towards new goals, also related to sustainability (Daugbjerg and Feindt 2017; Greer 2017; Schwindenhammer 2017).

At the EU level the decompartmentalization of agricultural policy can be witnessed especially since the Lisbon treaty, entering into force in 2009, that granted co-decision power to the European Parliament (EP) in the making of the Common Agricultural Policy (Greer 2017). Given the heterogeneity of political groups within the EP, this new decision-making power has contributed to the incorporation of new interests and demands in agricultural policy. However, there is a research gap regarding partisan differences in the EP in the field of agricultural policy. What are the policy positions of the political groups in the EP regarding agricultural policy and to what degree do these reflect 'old', e.g., food security and income support, and 'new' goals of agricultural policy such as sustainability and animal welfare issues? To explore these questions and possible partisan differences, the study on hand analyses debates in the EP by means of a discourse network analysis. Contrary to the analysis of voting results, discourses reveal policy preferences, varying perceptions of policy problems and suggested solutions to these problems.

The subsequent section starts with a literature overview on partisan politics in agricultural policy in the EP and develops hypotheses for the empirical analysis. Sect. 3 introduces the methodological procedure and the case selection. Sect. 4 presents the empirical data comprising the discourse networks of three policy proposals discussed in the 8th term of the EP. Sect. 5 closes with the discussion of findings, Sect. 6 draws conclusions regarding partisan differences in the EP. 


\section{Partisan politics in agricultural policy in the European Parliament}

Though the Common Agricultural Policy is in terms of spending still the most important policy area of the EU, political science studies on partisan differences in the EP have mostly focused on other policy areas such as economic, social or partly environmental policy. As a consequence, empirical evidence on the positioning of the political groups towards agricultural policy is scarce (Vogeler et al. 2021). Empirical studies on voting behaviour in EP decisions have found that though party cohesion is lower than in many national parliaments, the elected Members of Parliament (MEPs) have several incentives to vote with their political group. Political groups have been identified as key agenda-setters in the EP as they control finances, committee positions, speaking time during parliamentary debates as well as the legislative agenda (Hix et al. 2006; McElroy and Benoit 2011). Historically, the EP's political groups unite national parties at the European level that share similar ideological beliefs. In addition to the left-right dimension, an economic versus a social dimension and a positioning towards the degree of European integration are relevant in the context of party competition within the EP. Party cohesion is thus mainly based on ideological cohesion, the political groups do not necessarily share positions regarding specific policy issues, these are mostly worked out within the committees (Costello and Thomson 2016; Roger and Winzen 2014; Lord 2018). During the negotiations within the committees, intra-party coordination is particularly important, following the negotiations in the committees, the political groups fulfill the task to coordinate between committee members and other MEPs belonging to the group (Roger and Winzen 2014). Even at the national level the homogeneity of intra-party preferences can vary (Mader and Steiner 2019), which may affect policy positions. Homogeneity of preferences should be even lower at the EP level, given that different to the national level, MEPs at the EU level are torn between their political group at the EU level and their national interests and identity (Costello and Thomson 2016; Vogeler et al. 2020). Depending on the policy issue and on the national salience of an issue, MEPs may decide to defect from their political group line (Rasmussen 2008). In situations when political group and national positions clash, MEPs often opt for an abstention in the parliamentary vote (Mühlböck and Yordanova 2017). Despite these conflicts, the majority of empirical studies on decision-making in the EP find that political group membership remains an important predictor of MEPs voting behaviour (Mühlböck 2012; Hix et al. 2006).

An open research puzzle is the question how the groups position themselves towards agricultural policy and more specifically towards the integration of environmental and sustainability goals in this policy area. The scholarly debate subsumed in the prior section proposes the emergence of new ideas and interests in agricultural policy. Are these conflicting policy preferences reflected in the positioning and the votes of the political groups in the EP? Parliamentary work within the EP is organized in thematic committees. Within these committees elected Members of Parliament (MEPs) prepare and negotiate policy proposals for the according policy areas that are then decided upon in the plenary (Roger and Winzen 2014). Whereas historically the agricultural committee had the sovereignty in agricultural policymaking, the environmental committee has significantly expanded its influence on 
agricultural policymaking in the past years, especially in the areas of food safety and animal health. In addition, the composition of the agricultural committee itself has changed: with the increasing share of MEPs belonging to the green political group within the EP, the influence of producer interests has declined (RoedererRynning 2003). Despite this increasing diversity, it remains contested as to what degree economic and producer interests still prevail over environmental interests.

Analyses of decision-making in the EP show that political groups are in general less divided in the field of environmental policy. An exception are the Greens (Greens-EFA) who prioritize environmental protection even over economic growth; also for the left-wing GUE-NGL group environmental protection is an important goal (McElroy and Benoit 2011). One explanation for this missing environmental dimension in the EP is the fact that green parties have had a comparatively small share of seats in all prior terms of the EP (McElroy and Benoit 2011). Even in the 8th and 9th term their share remains limited. Evidence for the positive influence of MEPs belonging to the green party has been presented for the case of the agricultural committee, where the increasing participation of green MEPs has contributed to a stronger consideration of environmental goals in agricultural policy (Roederer-Rynning 2003). An empirical investigation of the voting behaviour of MEPs in farm animal welfare policies, as an important subfield of agricultural policy, has confirmed that only the Greens/EFA and the GUE/NGL unanimously voted for the introduction of animal welfare regulations, whereas cohesion in the other political groups was much less pronounced (Vogeler et al. 2020). Though the cited studies provide first indications for partisan differences, a systematic analysis of the positioning of the EP's political groups in the area of agricultural policy is missing. Accordingly, there is only limited knowledge on whether traditional agricultural views are still dominant among MEPs or whether the positioning of MEPs towards agricultural policy is more diversified already. Based on the current state of the literature three hypotheses are proposed that guide the empirical analysis. The intention is to collect empirical evidence regarding the current positioning and (re-)alignment of MEPs towards agricultural policymaking and prepare the ground for further analyses of MEPs behaviour in this policy field.

Hypothesis 1 assumes that the Greens/EFA will argue for the integration of environmental goals in agricultural policy.

Hypothesis 2 picks up the finding that within the EPP national parties unites that are historically close to farmers' interests. $\mathrm{H} 2$ proposes that MEPs belonging to the EPP are likely to promote traditional goals of agricultural policy related to the protection of the farming sector and the securing of farmers' incomes.

Hypothesis 3 ties in with the historical protection of the EU agricultural sector against external competition and the high degree of state intervention. Given the existence of a liberal political group in the EP, H 3 reads that the ALDE/ADLE positions itself against market interventions.

For the remaining political groups, the initial situation is less clear: for the rightwing and Eurosceptic groups neither agricultural nor environmental policy fall into 
their core issues. Accordingly, no systematic positioning is expected in these cases. The ensuing systematic analysis of the positions of MEPs in parliamentary debates in the EP makes a contribution to closing the depicted research gap. Whereas most empirical studies on the positions of political groups in the EP analyse voting behaviour, there is an emerging research strand that recognizes the potential of analysing parliamentary speeches (Proksch and Slapin 2009; Kaufmann 2020; Vogeler et al. 2021). The study on hand ties in with these studies and stands out by applying techniques of discourse network analysis to parliamentary debates (Leifeld 2020). This methodological approach is based on the assumption that competing policy preferences are expressed in public debates. Policymakers can strategically use plenary or public debates to present their preferred policy alternative and defend it against other conflicting policy alternatives and against political opponents. To explore these policy preferences and possible differences in the positioning of political groups, a systematic analysis of the discourses in the EP is conducted by means of a discourse network analysis. This method allows for the identification of shared discourse elements, policy preferences and opposing coalitions. Plenary debates in the EP are the last stage in the EP's policy-making process before the actual vote takes place. Negotiations take place prior within the thematic committees and within informal groups and decisions are prepared. Despite these limitations, longitudinal analyses show that plenary debates in the EP are used strategically by MEPs to give reasons for their preferred policy alternative and justify their decision (Lord and Tamvaki 2012). Accordingly, the analysis of discourses can be insightful for the assessment of political group positions and partisan differences in the EP. Compared to the statistical analysis of voting patterns, the inductive analysis of discourses allows to capture the arguments brought forward to justify a decision and thereby gain deeper insights into policy positions and partisan differences in agricultural policy.

The analysis is limited to the 8th term of the EP (elected in 2014 and lasted until the 2019 elections) with the aim to analyse recent positionings of MEPs towards agricultural policy. The limitation to one legislative term is chosen to have the same composition of political groups, this changes in every term. In the 8th EP, which is under study here, MEPs organized in eight political groups, in addition to a number of independent MEPs. The biggest group was the centre-right and conservative European People's Party (EPP) with 216 MEPs, followed by the Progressive Alliance of Socialist and Democrats (S\&D) with 185 MEPs. All other groups counted with less than 100 MEPs. The Eurosceptic Europeans Conservatives and Reformists (ECR) group was the third-largest group with 77 MEPs, followed by the liberal group Alliance of Liberals and Democrats for Europe (ALDE). Two groups, the European United Left-Nordic Green Left (GUE-NGL) and the GreensEuropean Free Alliance (Greens-EFA) had 52 MEPs each, both groups have an environmental focus. The Europe of Freedom and Direct Democracy (EFDD) counted with 42 MEPs and the Europe of Nations and Freedom (ENF) with 36 MEPs, both groups unite Eurosceptic and right-wing national parties. 


\section{Methods and case selection}

The empirical analysis builds upon a discourse network analysis to identify policy positions of the different MEPs within the EP and thereby draw conclusions on potential partisan differences. The analysis focuses solely on the discourses within the plenary debates of the European Parliament, as the principal public arena for the interchange and communication of policy positions beyond the committees and informal exchange. During these plenary debates also representatives of the European Commission (EC) are accredited speaking time to present the position of the EC. These statements are excluded in the following as commissioners or representatives of the EC are not affiliated to a political group of the EP and thus do not fall into the research interest of the study, which is the identification of partisan differences. The systematic analysis of plenary speeches with techniques of discourse network analysis (DNA) (Leifeld 2016, 2020) enables the reconstruction of discourses, the visualization of different policy positions and the uncovering of relations between these positions. DNA is a content-analytic approach that combines methods of network analysis with text and content analysis. The analysis begins with the coding of actors' statements in selected text documents such as media articles, policy documents or speeches. These statements are coded according to a previously defined and theoretically guided coding manual in a specifically designed software, the discourse network analyser. The collected data can then be exported to a visualization software, in this case Visone (Brandes and Wagner 2004), that is used to visualize relationships between actors and content in the coded material. Visone offers additional analytical functions such as the calculation of centrality or frequency of defined concepts or actors. The visualization of these relationships results in discourse networks that reveal different aspects of the discourse. The positions of the actors and the statements (concepts) in the discourse can then be interpreted to draw conclusions regarding the position of an actor within the discourse (centrality), the formation of actor coalitions within the discourse (actors sharing the same concepts) or the polarization of the discourse surrounding a specific policy issue. The method has been applied to different policy fields and departing from different theoretical frameworks to deepen the understanding of the policy process (Schaub and Metz 2020; Bandelow and Hornung 2019; Rinscheid et al. 2019; Nagel and Satoh 2018; Heikkila et al. 2014). The underlying idea is, that the visualization and analysis of discourse constellations and the relationships of actors within a discourse can help to acquire new knowledge on the policy process, e.g., the formation of coalitions or in our case the identification of conflicting or shared policy preferences in a defined policy field.

The study on hand aims to identify partisan differences in EU agricultural policy by analysing the discourses in the EP on specific issues concerning this policy area. Accordingly, three policy proposals have been chosen that were all voted on during the 8th term of the EP. The cases were selected in a multistage process. First, all parliamentary votes and the outcomes of the votes in the area of agriculture during the 8th term of the EP were searched on the platform VoteWatch. This first search resulted in 13 relevant cases. Out of these 13 cases, six were excluded because voting was highly consensual, meaning that the share of against votes or abstentions 
was comparatively low which makes it unlikely to draw conclusions on partisan differences. From the remaining seven policies, three were chosen for the empirical analysis that represent different areas of agricultural policy: The first policy proposal deals with market intervention policies and more specifically with the protection of the dairy sector. The second policy proposal is from the area of farm animal welfare, proposing EU welfare regulations for commercial rabbit farming. The third policy proposal deals with the future alignment of the CAP and the general goals of agricultural policy.

The analysis comprises the plenary debates prior to the votes on each policy proposal. The statements of MEPs within the debates were coded as so-called concepts that then appear in the visualization as nodes. The concepts were derived inductively by paraphrasing at a minimal level of abstraction and sorting the concepts into categories. A statement of one actor-in this case MEP — can include different concepts, when he or she refers to different things in his or her speech. The coding included the affiliation of each MEP to a political group. The resulting data were then analysed at the two-mode level to visualize actors and statements (concepts) in relation to each other. This relationship is evaluated dichotomously to indicate agreement (visualized in light grey in the networks) or disagreement (dark grey) with a statement. The coding of the material from the three parliamentary debates resulted in a total of 636 statements (348 for the dairy package case, 71 for the rabbit case and 217 for the future of farming case). The cases were coded separately in DNA and then exported as two-mode networks (one network for each case), including the combination of organizational affiliation (in this case political group) and concept (content).

In Table 1 an overview of the voting results for the three cases is provided. The table includes the lines of the political group (which does not necessarily mean that all MEPs voted along the group line). For all participants in the debate the individual votes were compared with their party group line (available on the platform VoteWatch). In the dairy package case out of the 52 MEPs who delivered speeches only 6 defected from their group line. In the rabbit protection case 1 out of eleven speakers defected from the group line and in the future of farming policy only 7 out of 36 speakers voted different than the political group. As the mere focus on voting results does not provide information on the reasons for the group position

Table 1 Case selection. (Source: own compilation based on data from the European Parliament)

\begin{tabular}{lllll}
\hline Policy & Date & Votes For (in \%) & Votes Against (in \%) & Abstentions (in \%) \\
\hline $\begin{array}{l}\text { Review of the } \\
\text { implementation of }\end{array}$ & 2015 & 72 & 22 & 6 \\
the dairy package & & EPP, ALDE, ECR, & GUE-NGL, & - \\
Minimum standards & 2017 & ENF, S\&D & Greens/EFA, EFDD & \\
$\begin{array}{l}\text { for the protection of } \\
\text { farm rabbits }\end{array}$ & & GUE-NGL, & 30 & - \\
& & Greens/EFA, ALDE, & & \\
The future of food & \multirow{2}{*}{2018} & ECR, S\&D & & \\
and farming & & ALDE, ECR, ENF, & EFDD, GUE-NGL & Greens/EFA \\
& & EPP, S\&D & \\
\hline
\end{tabular}


and on why MEPs decided to vote for a chosen policy position, these questions will be explored by the analysis of discourses.

\section{Results}

The empirical results are in the first place presented for each case separately. Subsequently the findings will be discussed in comparison. In addition to this visualization of the three networks (Figs. 1, 2 and 3) the most central political groups and the ten most central concept for each discourse network have been extracted and are listed in the appendix as separate tables.

\subsection{Dairy package}

The review of the implementation of the dairy package discussed in Parliament in 2015 dealt with the difficult situation and the future circumstances of the European dairy sector. Background of the challenging situation is the expiration of milk quotas in March 2015 and the high volatility in prices that threatens the income and

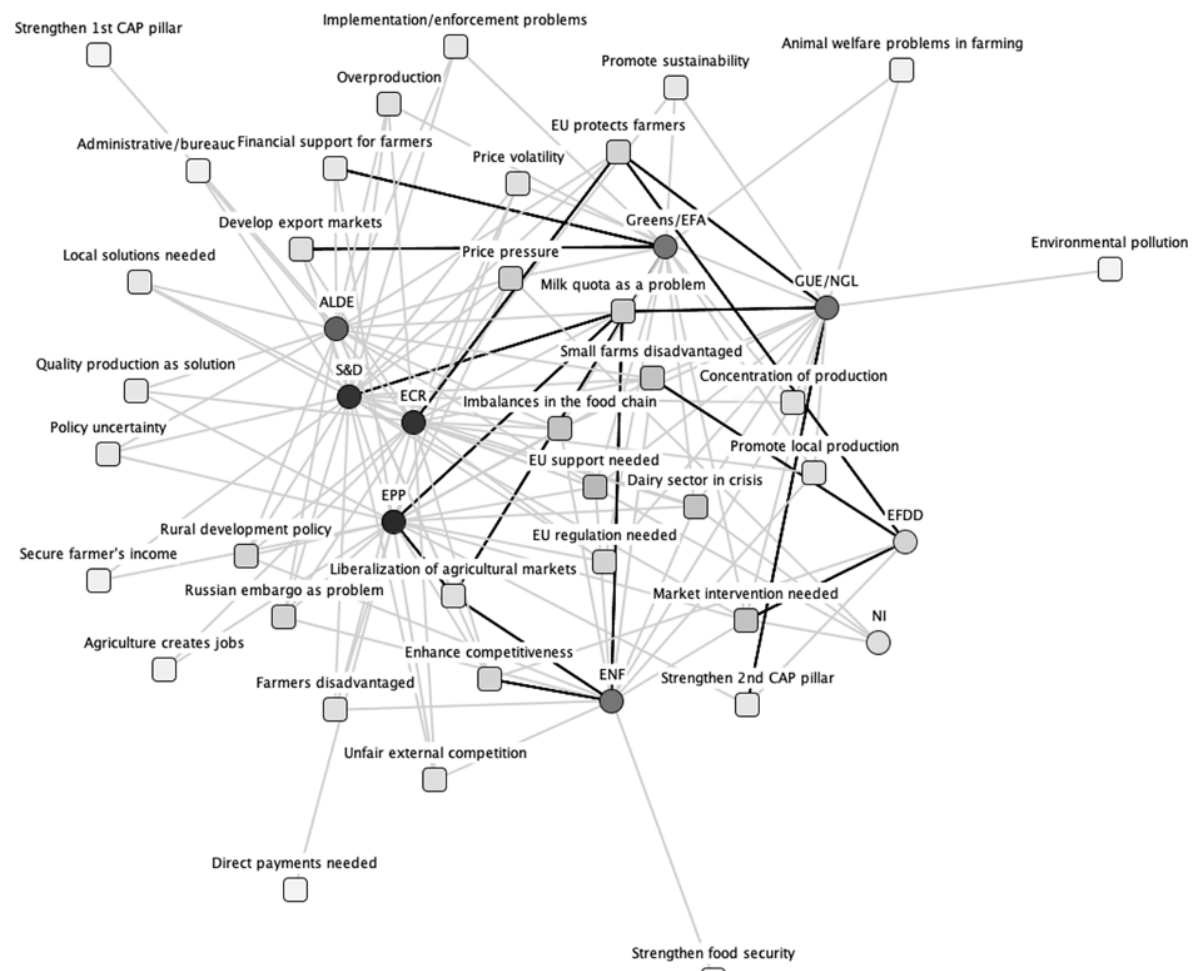

Fig. 1 Discourse network of the EP plenary discussion on the dairy package (2015) (dark grey lines indicate agreement, light grey lines indicate disagreement with concepts; the darker the nodes, the more central an actor or concept is in the discourse). (Source: own design) 


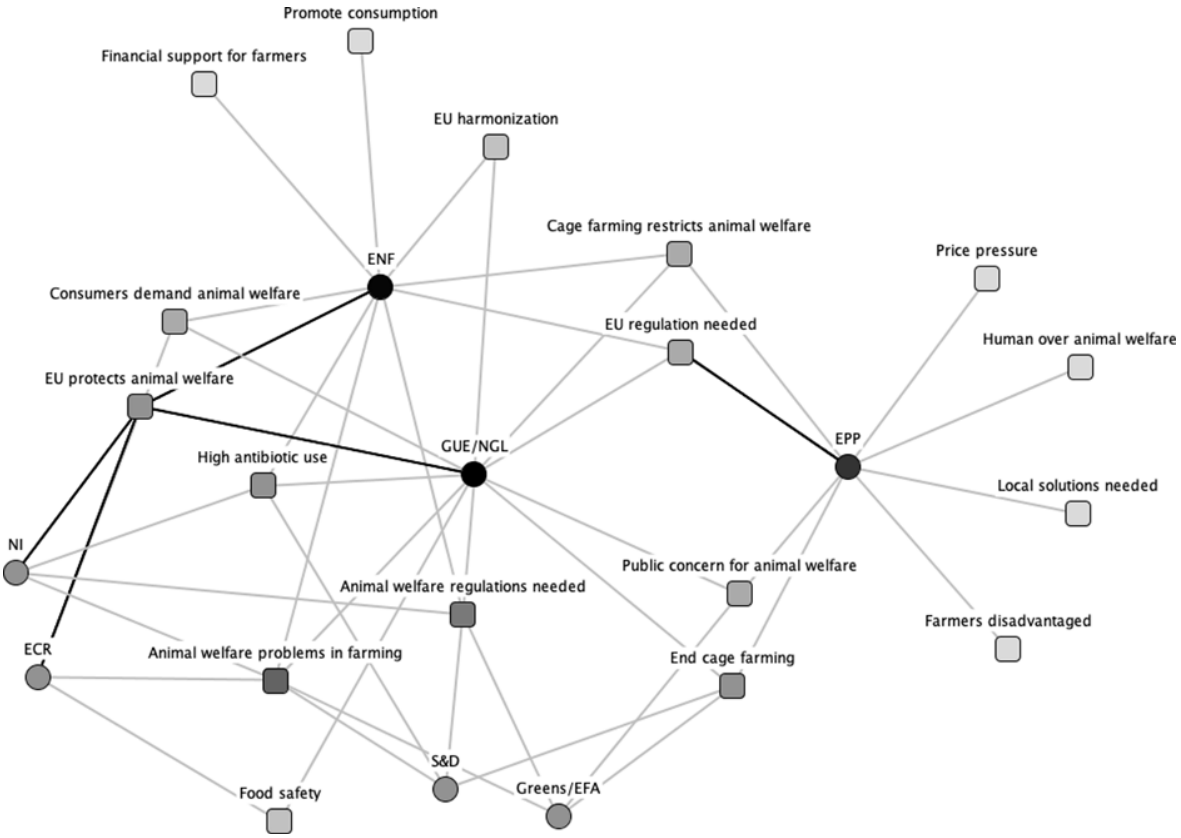

Fig. 2 Discourse network of the EP plenary discussion on the Protection of Farm Rabbits (2017) (dark grey lines indicate agreement, light grey lines indicate disagreement with concepts; the darker the nodes, the more central an actor or concept is in the discourse). (Source: own design)

existence of dairy farmers. These market pressures were exacerbated by the Russian embargo on EU dairy products in place since August 2014. With the own-initiative report the EP calls on the EC to create new financing opportunities for member states to support the sector and to take measures to mitigate risks (European Parliament 2014). The proposal includes the promotion of the development of new export markets in order to stimulate production. The necessity to support the sector and strengthen its competitiveness against external competition was justified with the high environmental and animal welfare standards that EU dairy farmers have to comply with, creating a competitive disadvantage. In the report, the important role of the dairy sector for rural development and land management is pointed out, especially in disadvantaged regions. Small-scale farmers are described as particularly vulnerable in face of the market imbalances and in need of income support in times of crises.

The report was approved in Parliament with a majority of $72 \%$ (Table 1). Despite the high number of MEPs voting for the proposal, MEPs of three political groups voted against the policy, namely from the Greens/EFA, the GUE-NGL and interestingly also from the EFDD. From the EFFD all MEPs voted against the proposal, only five out of the 52 GUE-NGL MEPs and four out of the 53 Greens/EFA MEPs voted for the policy proposal. Interestingly, MEPs from the EPP and the liberal ALDE group unanimously voted for the policy (with two abstentions in the EPP and eight in the ALDE group). Among S\&D MEPs the picture is less clear, whilst 


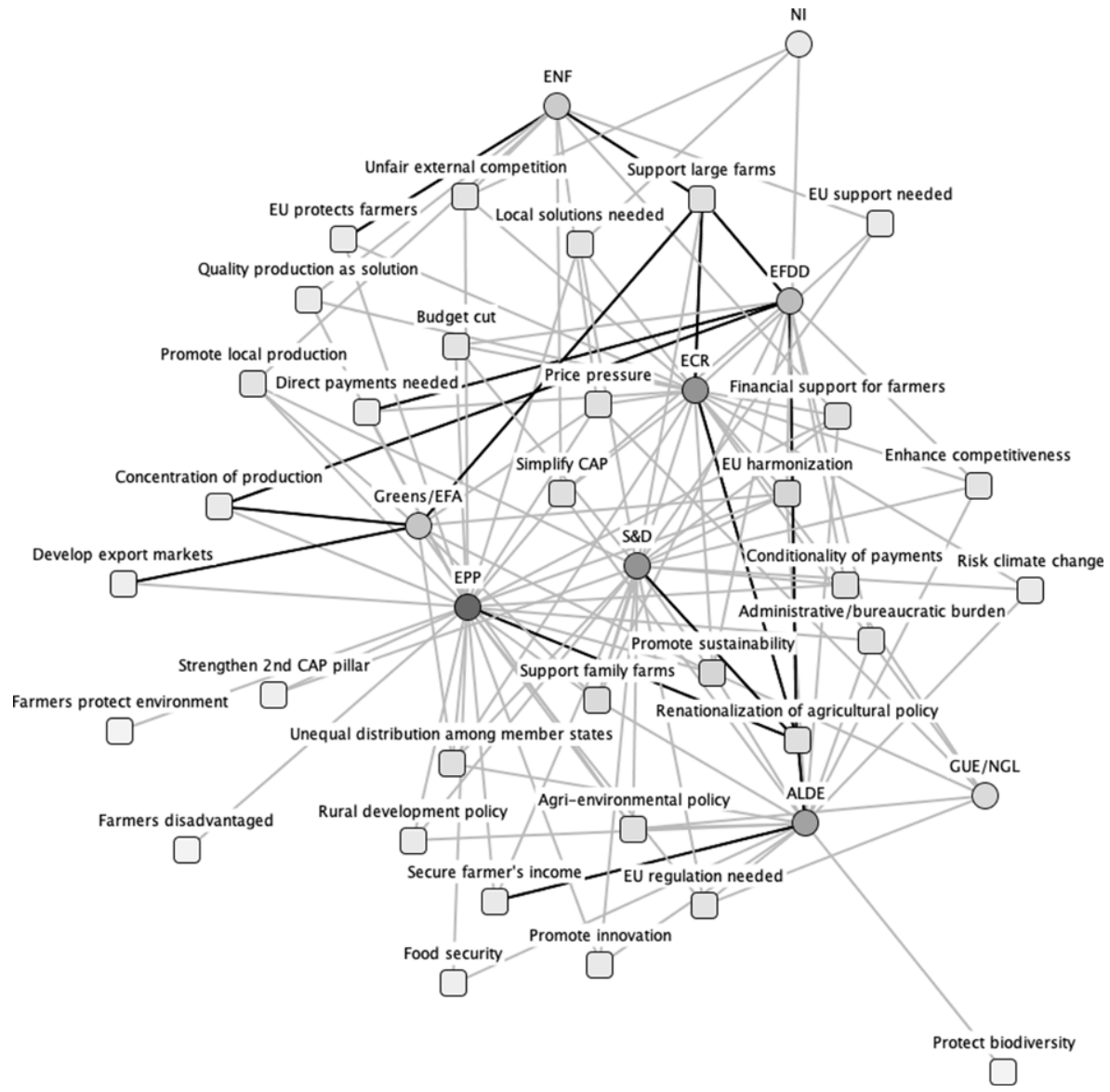

Fig. 3 Discourse network of the EP plenary discussion on the Future of Food and Farming (2018) (dark grey lines indicate agreement, light grey lines indicate disagreement with concepts; the darker the nodes, the more central an actor or concept is in the discourse). (Source: own design)

a majority did approve the policy, a considerable share of MEPs also voted against it. What arguments do MEPs give for their policy preferences? In Fig. 1 the discourse is visualized, the darker the nodes, the more central an actor or concept is in the discourse.

The visualization firstly reveals the intensive and partly conflictive (indicated by the red lines) debate surrounding the dairy package. The number of different concepts shows the different problem perceptions and policy solutions that the political groups talk about. The most central actors within the network are the ECR, the S\&D and the EPP followed by the ALDE. The GUE/NGL and the Greens/EFA are located at the right margin of the network, indicating that they do not share as many concepts with the other groups, both groups opposed the policy. There is a certain degree of consensus across political groups that the dairy sector is facing a crisis and that EU support is needed, however, the positions regarding the reasons 
and the solutions to this challenge vary greatly. One reason for the crisis that is comparatively consensual is the end of the milk quota, though there is disagreement on the evaluation of the milk quota in general. MEPs from the ALDE consider the milk quota as a market disturbing intervention, whereas S\&D MEPs do not see the quota as a problem. Among MEPs from the ECR and the GUE/NGL both views are found. Another reason for the crisis of the milk sector is the Russian embargo, which is uncontroversial in the discourse. A further reason for the crisis that is raised frequently by MEPs of almost all groups are the imbalances in the food chain at the disadvantage of farmers. This includes the power of food processors, retailers and large industrial companies as compared to the weak farmers that have to sell their milk often even below production prices. Connected to this is the price pressure and the price volatility in the market, challenges also named by MEPs from all political groups. Another frequently raised reason for the crisis that is named by the ECR, the S\&D and also the EPP is the unfair external competition due to higher standards in the EU that increase production prices for EU farmers. Accordingly, the liberalization of agricultural markets is considered as a challenge rather than as a solution to the crisis by the EPP and the Greens/EFA. The only group in support of the liberalization is the ALDE.

Regarding the solutions to the crisis, the visualization of the discourse reveals much more conflicting policy preferences as compared to the problem perception. The MEPs from the EPP focus on financial support for farmers and the securing of income by direct payments and the promotion of consumption to stimulate production. In addition, they aim at the development of export markets to increase production, an idea that is shared by ALDE and partly S\&D MEPs but opposed by the Greens/EFA. Contrary to that, the Greens/EFA as well as the GUE/NGL are against uncoupled financial support and highlight the environmental dimension: they raise the environmental and animal welfare problems of some farming practices such as manure handling and the need to support sustainability. Partly, these sustainability issues are also raised by MEPs from the ECR. The ECR argues in favour of local solutions and the need to support family farms, and criticizes insufficient EU support to protect farmers. In sum, the visualization reveals the relative agreement that EU support is needed for the dairy sector. Disagreement is found regarding the reasons for the crisis and even more with regard to the policy solutions and the appropriate policy instruments. These conflicting policy preferences clearly point towards a party political dimension.

\subsection{Protection of farm rabbits}

In 2017 the European Parliament voted on an own-initiative procedure in the area of farm animal welfare policy. The policy proposal aimed at the introduction of EU regulations for commercial rabbit farming. Rabbits are in numbers the second-most farmed species in the EU. The proposal was preceded by a debate in the EP's intergroup on the welfare and conservation of animals, that outlined serious welfare and health challenges in commercial rabbit farming (Intergroup on the welfare and conservation of animals 2015). These problems were also highlighted by the European Food Safety Authority (EFSA) that criticized the dominating forms of cage-farm- 
ing as being associated with extremely low welfare and high mortality rates (EFSA 2005). Picking up these concerns the EP's own-initiative procedure proposed to introduce EU legislation for commercial rabbit farming and recommended the move to pen-house systems to replace current cage systems to improve animal welfare (European Parliament 2017). Though the policy proposal received a majority within Parliament, the Commission later on denied to introduce legislation. The EC reasoned that given the high concentration of rabbit farming-Spain, France and Italy account for over $80 \%$ of production-national instead of EU regulation was needed. The contestation over whether new legislation should be passed to protect farmed rabbits also manifested during the plenary debate and the vote in the EP. Though the policy was approved with a majority of about two-thirds, one third of MEPs voted against it. The voting results shows that the Greens/EFA and also the GUENGL unanimously voted for the proposal. Other groups that in the majority voted for the policy were the S\&D, the ALDE as well as the ECR group. On the contrary, the vast majority of MEPs from the EPP voted against it, following the line of their political group on this issue. Only MEPs from the ENF and the EFDD did not show uniform voting behaviour. In Fig. 2 the results of the discourse network analysis on this specific policy proposal are visualized. The darker the nodes, the more central the actor or concept is in the discourse.

Recognisable at first sight are the central positions of the EPP on the right side and the GUE/NGL in the middle/left of the network. The statements of MEPs from these groups differ considerably. MEPs from the EPP argue that additional animal welfare regulations are a competitive disadvantage in view of external competition, that the rights of farmers must also be respected and that price pressure is already high. They argue that EU regulations are not a solution and that instead local solutions are needed. Despite these arguments against this specific farm animal welfare policy, they also bring arguments in favour of animal welfare in general, e.g., recognizing that there is a rising public concern for animal welfare and that some production practices such as cage farming can restrict animal welfare. The argument that there are general animal welfare problems in farming, e.g., related to cage farming or the rising public concern, are shared with the Greens/EFA and the GUE/NGL and partly also with the S\&D and the ENF. Accordingly, there seems to be a certain consensus that animal welfare is important in agricultural production. However, differences prevail in the discourse. Especially the MEPs from the GUE/NGL and the Greens/EFA point to animal welfare problems and cruelty in farming and plead in favour of EU regulations and the harmonization of standards. The GUE/NGL, the ECR and also the ENF MEPs agree that the EU does not sufficiently protect animal welfare as the red lines indicate. Especially the GUE/NGL but also the S\&D and the ENF link their arguments for animal welfare to other policy areas such as high antibiotic use. By this, they stress the importance and influence of animal welfare for neighbouring policy areas. Summarizing, the visualization of the discourse reveals high degrees of polarization, with traditional agricultural goals focused on the interest of farmers and economic productivity on the one side and animal welfare goals on the other side. Interestingly, in this specific case the EPP is relatively alone with the first position whereas there is a diverse coalition of MEPs from different political groups promoting the latter. 


\subsection{Future of food and farming}

The third policy under analysis concerns the future design of the CAP and is an owninitiative procedure by the EP which was voted on in May 2018. The report forms part of the policy process surrounding the future of the CAP after 2020 and was a reaction to a proposal from the EC from 2017. The proposal dealt with the general corner stones of EU agricultural policy as well as with specific policy instruments, such as the strengthening or weakening of the second pillar of the CAP, direct income payments and the role and design of environmental measures (European Parliament 2018). The motion for a resolution was approved by Parliament with a majority of only $69 \%$. This majority was built mainly by the EPP MEPs who, with the exception of four MEPs, all voted for the policy, the S\&D, here only 16 MEPs voted against it or abstained, and the ALDE MEPs of whom two thirds voted for it. However, the other third of ALDE MEPs voted against the policy, which reveals highly conflicting policy preferences regarding this policy within this political group. Similar patterns can be found for ECR and ENF: in both groups a majority voted for the policy, but also a large number of MEPs voted against it in both groups. Equally unclear is the voting behaviour of EFDD, though the party group line was against the policy, a high number of MEPs also voted for the policy, making up only a small majority against the policy. More uniformity is found among GUENGL and Greens/EFA MEPs, in both cases the majority followed the political group line. Interestingly, for the Greens/EFA the group proposed to abstain, the GUE-NGL group voted against (Fig. 3).

The number of different concepts in the discourse network reveals the variety of policy positions regarding the future alignment of the CAP, the red lines indicate the conflicting policy preferences. The EPP and the ECR are the most central actors in the network whereas the Greens/EFA, the GUE/NGL and the ALDE are rather isolated at margins of the network. EPP deputies stress the disadvantaged role of farmers and the price pressure and therefore argue that the CAP must support farmers by means of direct payments and rural development policies. In addition, they emphasize the unfair role of external competition, the need to intervene in the market and to assist farmers in developing export markets. In addition to these mostly traditional agricultural policy goals, they also stress the need to integrate new demands in the CAP, for example by providing incentives for sustainability, e.g., by strengthening the second pillar of the CAP and support quality protection. Given the number of tasks of EU agricultural policy, EPP MEPs speak out against a further renationalization of the CAP. This position is also shared by the $S \& D$, the ALDE and the EFDD. Connected to this is the need of EU harmonization, a policy preference that is shared by Greens/EFA, S\&D, EPP and ALDE. Other concepts that are shared by the EPP, the S\&D, ECR and ALDE relate to the general need to support farmers and to the need to simplify the CAP and reduce administrative or bureaucratic burdens for farmers. Consensual among MEPs from almost all groups is the need to support especially small and family farms, also given their contribution to rural development. The ENF even speaks out against the support for large farms and criticizes the increasing liberalization of agricultural markets. The network further illustrates several shared policy preferences between EPP and ECR 
MEPs. The ECR also pleads for income and financial support for farmers whereas at the same time they stress the need to create incentives for sustainability. For the Greens/EFA the most important issues in the future CAP are sustainability and the better support of agri-environmental measures, e.g., incentives to reduce pesticides in order to strengthen resilience. The GUE/NGL shares the view that environmental measures should be strengthened but also points to the difficult situation of farmers. They plead for a stronger conditionality of payments and speak out against voluntary policies. Environmental goals are also found in the positioning of ALDE MEPs, such as the protection of biodiversity and the increasing risk of climate change for agriculture. At the same time the ALDE, contrary to other groups, stresses the individual responsibility of farmers and the need to enhance competitiveness and promote innovation. In sum, though there are some general lines of agreement, e.g., the need to support farmers and their important role for rural development, the discourse is mainly dominated by conflicting views on the future design of the CAP. Whereas especially the EPP wants to stick with direct payments and income support, though recognizing also the need to integrate sustainability, GUE/NGL and Greens/EFA as well as ALDE plead for a reorganization of agricultural policy, along environmental goals and in the latter case by increasing competitiveness and individual responsibility. The S\&D has a rather moderating position, sharing preferences regarding income support measures as well as sustainability issues.

\section{Discussion of findings}

How do political groups position themselves towards agricultural policy and in particular towards the integration of environmental and sustainability goals therein? Are there partisan differences and do these reflect either the 'old' or the 'new' goals of agricultural policy? The comparative analysis of three controversial debates in the EP on different policy proposals, has revealed important findings regarding partisan differences. By means of a discourse network analysis shared and conflicting policy preferences were identified. First evidence for partisan differences can be found already in the voting results. The analysis of the discourses preceding the votes proved insightful for exploring policy preferences and the reasons for the observed voting patterns.

Regarding the developed hypotheses the empirical analysis clearly confirms hypothesis 1: MEPs from the Greens/EFA argue in all three cases for the integration of environmental and sustainability goals as well as animal welfare in agricultural policy. Interestingly, the GUE/NGL has many shared policy preferences with the Greens/EFA. In the discourse networks they are located next to each other and have a number of shared concepts, in particular regarding environmental, but also regarding animal welfare goals. A second thematic focus of the GUE/NGL group is the difficult situation of farmers in the market and the need to protect them. Uniting national parties from the left spectrum, this reflects their emphasis on equality and redistribution.

Hypothesis 2 proposed that MEPs belonging to the EPP are likely to promote traditional goals of agricultural policy related to the protection of the agricultural 
sector and the securing of farmers' incomes. This hypothesis can be confirmed across all three policies. The discourse of the EPP is dominated by concepts such as securing farmers' income, direct payments and the protection of the farming sector. However, at the same time the networks reveal that MEPs from the EPP also refer to the need to promote sustainability and environmental goals in agricultural policy. Though at several points MEPs from the EPP also highlight the cost of environmental and especially animal welfare measures for farmers and the competitive disadvantages related to these. These findings indicate that there is now a broader consensus on the diversification of agricultural goals also within political groups that are historically close to the agricultural sector.

Hypothesis 3 expected that the liberal ALDE group positions itself against the interventionist character of agricultural policy and market protection. The first remarkable finding for the ALDE is, that their positions on agricultural policy are extremely diverse, including environmental and animal welfare goals and the acknowledgment of the importance of rural development policies. At the same time, the three discourses clearly reveal policy preferences regarding a liberalization of agricultural markets, the strengthening of competitiveness and innovative capacities of the farming sector as well as the individual responsibility of farmers within the market. Accordingly, hypothesis 3 can also be confirmed.

Despite the confirmation of hypotheses 2 and 3, the empirical results reveal that both, ALDE and EPP have more differentiated policy positions than expected. MEPs from both groups acknowledge the increasing complexity of agricultural policy and the need to reconcile farmers, environmental and market demands alike. For the remaining groups no initial hypotheses were derived from the literature. However, the empirical analysis also reveals interesting findings for several of these groups. Especially MEPs from the ECR and the ENF participate actively in all three parliamentary debates. They raise environmental and animal welfare issues more frequently than their counterparts of the EPP. The ENF at the same time argues that the agricultural sector and farmers deserve protection by the EU and at several points speaks out against the liberalization of agricultural markets. Though the ECR also recognizes the need to support farmers and the importance of rural development policies, it also stresses the individual responsibility of farmers and the need to find local solutions. Both, MEPs from the ECR and the ENF blame the EU for not sufficiently protecting farmers, which reveals their generally Eurosceptic position.

\section{Conclusion}

With regard to partisan differences in EU agricultural policy, the analysis of parliamentary discourses revealed that there are indeed important differences in problem perceptions and preferred policy solutions. The comparative analysis of three policies concerning different areas of agricultural policy show a clear party political dimension. Substantive differences are found between the EPP on the one hand and the Greens/EFA and the GUE/NGL on the other hand, with the EPP standing for traditional agricultural goals and the Greens/EFA and the GUE/NGL promoting a change towards an environmentally and animal welfare friendly agricultural policy. 
The latter position is supported by the ALDE but surprisingly also by the ECR and the ENF.

At the same time, it is astonishing that MEPs from all political groups recognize the need to integrate sustainability concerns in future agricultural policy. This finding reflects the increasingly complex and dynamic character of agricultural policymaking. Future studies should build on these findings by expanding the analysis to other policies in the domain of agricultural policy and in particular to the 9th term of the European Parliament. Questions that could be addressed include if the increasing share of environmental parties in this legislative period leads to a more holistic consideration of environmental goals in agricultural policy. Another gap for future research is the question whether the increasing public and media attention for environmental and climate change issues leads to a convergence of political group positions also in the area of agricultural policy.

Supplementary Information The online version of this article (https://doi.org/10.1007/s12286-02100496-3) contains supplementary material, which is available to authorized users.

Funding Open Access funding enabled and organized by Projekt DEAL.

Open Access This article is licensed under a Creative Commons Attribution 4.0 International License, which permits use, sharing, adaptation, distribution and reproduction in any medium or format, as long as you give appropriate credit to the original author(s) and the source, provide a link to the Creative Commons licence, and indicate if changes were made. The images or other third party material in this article are included in the article's Creative Commons licence, unless indicated otherwise in a credit line to the material. If material is not included in the article's Creative Commons licence and your intended use is not permitted by statutory regulation or exceeds the permitted use, you will need to obtain permission directly from the copyright holder. To view a copy of this licence, visit http://creativecommons.org/licenses/by/4. $0 \%$

\section{References}

Alons, Gerry. 2017. Environmental policy integration in the EU's common agricultural policy: greening or greenwashing? Journal of European Public Policy 24(11):1604-1622. https://doi.org/10.1080/ 13501763.2017.1334085.

Bandelow, Nils C., and Johanna Hornung. 2019. One discourse to rule them all? Narrating the agenda for labor market policies in France and Germany. Policy and Society 38(3):408-428. https://doi.org/10. 1080/14494035.2019.1641379.

Brandes U., Wagner D. 2004. Analysis and Visualization of Social Networks. In: Jünger M., Mutzel P. (eds) Graph Drawing Software. Mathematics and Visualization. Springer, Berlin, Heidelberg. https:// doi.org/10.1007/978-3-642-18638-7_15.

Lord Christopher, and Dionysia Tamvaki. 2012. The politics of justification? Applying the 'discourse quality index' to the study of the European parliament. European Political Science Review 5(1):27-54. https://doi.org/10.1017/s1755773911000300.

Coleman, William D., Grace D. Skogstad, and Michael M. Atkinson. 1996. Paradigm shifts and policy networks: cumulative change in agriculture. Journal of Public Policy 16(03):273. https://doi.org/10. 1017/s0143814x00007777.

Costello, Rory, and Robert Thomson. 2016. Bicameralism, nationality and party cohesion in the European Parliament. Party Politics 22(6):773-783. https://doi.org/10.1177/1354068814563972.

Daugbjerg, Carsten, and Peter H. Feindt. 2017. Post-exceptionalism in public policy: transforming food and agricultural policy. Journal of European Public Policy 24(11):1565-1584. https://doi.org/10. 1080/13501763.2017.1334081.

Daugbjerg, Carsten, and Alan Swinbank. 2016. Three decades of policy layering and politically sustainable reform in the European Union's agricultural policy. Governance 29(2):265-280. https://doi.org/10. 1111 gove.12171. 
EFSA. 2005. Opinion of the Scientific Panel on Animal Health and Welfare (AHAW)on a request from the Commission related to" "The Impact of the current housing and husbandry systems on the health and welfare of farmed domestic rabbits. EFSA Journal https://doi.org/10.2903/j.efsa.2005.267.

European Parliament. 2014. Committee report tabled for plenary, single reading 2014/2146(INI) - 15/06/2015 edited by Legislative Observatory.

European Parliament. 2017. Report on minimum standards for the protection of farm rabbits. Brussels: European Parliament.

European Parliament. 2018. Future of food and farming. Brussels: European Parliament. edited by Legislative Observatory.

Grant, Wyn P. 2017. Can political science contribute to agricultural policy? Policy and Society 31(4): 271-279. https://doi.org/10.1016/j.polsoc.2012.09.001.

Greer, Alan. 2017. Post-exceptional politics in agriculture: an examination of the 2013 CAP reform. Journal of European Public Policy 2(2):1-19. https://doi.org/10.1080/13501763.2017.1334080.

Heikkila, Tanya, Christopher M. Weible, and Jonathan J. Pierce. 2014. Exploring the policy narratives and politics of hydraulic fracturing in New York. In The science of stories, 185-205.

Henke, Roberto, Theo Benos, Fabrizio De Filippis, Mara Giua, Fabio Pierangeli, and Maria Rosaria Pupo D'Andrea. 2018. The new common agricultural policy: How do member states respond to flexibility? JCMS: Journal of Common Market Studies 56(2):403-419. https://doi.org/10.1111/jcms.12607.

Hix, Simon, Abdul Noury, and Gerard Roland. 2006. Dimensions of politics in the European parliament. American Journal of Political Science 50(2):494-520. https://doi.org/10.1111/j.1540-5907. 2006.00198.x.

Intergroup on the welfare and conservation of animals. 2015. Rabbit welfare-issues and solutions. Brussels: Eurogroup for animals.

Kaufmann, David. 2020. Debating responsibility-sharing: an analysis of the European Parliament's debates on the Common European Asylum System. European Policy Analysis https://doi.org/10.1002/epa2. 1087.

Leifeld, Philip. 2016. Policy debates as dynamic networks. German pension politics and privatization discourse. Frankfurt, New York: Campus.

Leifeld, Philip. 2020. Policy debates and discourse network analysis: a research agenda. Politics and Governance https://doi.org/10.17645/pag.v8i2.3249.

Lord, Christopher. 2018. The European Parliament: a working parliament without a public? The Journal of Legislative Studies 24(1):34-50. https://doi.org/10.1080/13572334.2018.1444624.

Mader, Matthias, and Nils D. Steiner. 2019. Party institutionalization and intra-party preference homogeneity. Zeitschrift für Vergleichende Politikwissenschaft 13(2):199-224. https://doi.org/10.1007/s12286019-00421-9.

McElroy, Gail, and Kenneth Benoit. 2011. Policy positioning in the European Parliament. European Union Politics 13(1):150-167. https://doi.org/10.1177/1465116511416680.

Möck, Malte, Colette S. Vogeler, Nils C. Bandelow, and Boris Schröder. 2019. Layering action situations to integrate spatial scales, resource linkages, and change over time: the case of groundwater management in agricultural hubs in Germany. Policy Studies Journal https://doi.org/10.1111/psj.12377.

Mühlböck, Monika. 2012. National versus European: party control over members of the European parliament. West European Politics 35(3):607-631. https://doi.org/10.1080/01402382.2012.665743.

Mühlböck, Monika, and Nikoleta Yordanova. 2017. When legislators choose not to decide: abstentions in the European Parliament. European Union Politics 18(2):323-336. https://doi.org/10.1177/ 1465116517694369.

Nagel, Melanie, and Keiichi Satoh. 2018. Protesting iconic megaprojects. A discourse network analysis of the evolution of the conflict over Stuttgart 21. Urban Studies 56(8):1681-1700. https://doi.org/10. $1177 / 0042098018775903$.

Proksch, Sven-Oliver, and Jonathan B. Slapin. 2009. Position taking in European parliament speeches. British Journal of Political Science 40(3):587-611. https://doi.org/10.1017/s0007123409990299.

Rasmussen, Anne. 2008. Party soldiers in a non-partisan community? Party linkage in the European Parliament. Journal of European Public Policy 15(8):1164-1183. https://doi.org/10.1080/ 13501760802407672.

Rinscheid, Adrian, Burkard Eberlein, Patrick Emmenegger, and Volker Schneider. 2019. Why do junctures become critical? Political discourse, agency, and joint belief shifts in comparative perspective. Regulation \& Governance https://doi.org/10.1111/rego.12238.

Roederer-Rynning, Christilla. 2003. From 'talking shop' to 'working parliament'? The European parliament and agricultural change. JCMS: Journal of Common Market Studies 41(1):113-135. https://doi. org/10.1111/1468-5965.t01-1-00413. 
Roger, Léa, and Thomas Winzen. 2014. Party groups and committee negotiations in the European Parliament: outside attention and the anticipation of plenary conflict. Journal of European Public Policy 22(3):391-408. https://doi.org/10.1080/13501763.2014.941379.

Schaub, Simon, and Florence Metz. 2020. Comparing discourse and policy network approaches: evidence from water policy on micropollutants. Politics and Governance https://doi.org/10.17645/pag.v8i2. 2597.

Schwindenhammer, Sandra. 2017. Global organic agriculture policy-making through standards as an organizational field: when institutional dynamics meet entrepreneurs. Journal of European Public Policy 24(11):1678-1697. https://doi.org/10.1080/13501763.2017.1334086.

Skogstad, Grace. 1998. Ideas, paradigms and institutions: agricultural exceptionalism in the European Union and the United States. Governance 11(4):463-490. https://doi.org/10.1111/0952-1895.00082.

Töller, Annette Elisabeth. 2010. Measuring and comparing the Europeanization of national legislation: a research note. JCMS: Journal of Common Market Studies 48(2):417-444. https://doi.org/10.1111/ j.1468-5965.2009.02058.x.

Tosun, Jale. 2017. Party support for post-exceptionalism in agri-food politics and policy: Germany and the United Kingdom compared. Journal of European Public Policy https://doi.org/10.1080/13501763. 2017.1334083.

Vogeler, Colette S. 2019. Why do farm animal welfare regulations vary between EU member states? A comparative analysis of societal and party political determinants in France, Germany, Italy, Spain and the UK. JCMS: Journal of Common Market Studies 57(2):317-335. https://doi.org/10.1111/jcms. 12794.

Vogeler, Colette S., Johanna Hornung, and Nils C. Bandelow. 2020. Farm animal welfare policymaking in the European Parliament-a social identity perspective on voting behaviour. Journal of Environmental Policy \& Planning https://doi.org/10.1080/1523908x.2020.1778458.

Vogeler, Colette S., Sandra Schwindenhammer, Denise Gonglach, and Nils C. Bandelow. 2021. Agrifood technology politics: Exploring policy narratives in the European Parliament. European Policy Analysis https://doi.org/10.1002/epa2.1114. 